\title{
ARTICLE
}

\section{A factor analysis of characterization of "Politician" criteria by different generations in Mongolia}

\author{
Ariunsan Gantuya ${ }^{1 *}$ and Jargalsaikhan Oyunsuren ${ }^{2}$ \\ ${ }^{1}$ School of International \& Public Affairs, \\ Shanghai Jiaotong University, Shanghai, PRC \\ ${ }^{2}$ School of International Relations \& Social Studies, \\ University of the Humanities, Ulaanbaatar, Mongolia
}

ARTICLE INFO: Received: 20 Aug, 2019; Accepted: 9 Dec, 2019

\begin{abstract}
Based on intergeneration theories, 2721 randomly sampled pollees are classified into 4 generations; namely Gen Z, Gen Y, Gen X and Gen BB. This paper aims to identify the difference between Mongolian generations, especially on subjective criteria to assess politicians. Based on the statistical result of factor analysis, 20 criteria are classified into 5 factors. KMO measurements above .800 and absolute significance value above .30 is used to set the boundaries for criteria grouped in one category and overlapping criteria are examined with ground justifications. Public perception of potential political representatives is researched among each generation, and commonality and discrepancies among generations are explained with quantitative verifications in the following paper. Statistics results reveal that there are common factors between Gen $Z$ and $Y$, in which they perceive the factors such as the qualification and the public skills in a similar manner. Also, older generations including Gen X and BB have uniform understanding of education and political experience of politicians.
\end{abstract}

Keywords: politician criteria; generations in Mongolia; factor analysis; intergeneration study;

\section{INTRODUCTION}

Mongolia as a good example of democratization since 1990, has successfully adopted crucial elements of democracy including free and fair political elections, free press and protection of human rights. In the last three decades, Mongolians have built a strong foundations of democratic political culture and have understood the meaning and signficance of political participation and at the least, the importance of electoral vote. Despite current global trends in rising populism, it is crucial to study the thinking of Mongolians on politics and common criteria for assessing potential political representatives.

Setting criteria for a politician is highly subjective [1] and controversial since the criteria used in theoretical studies are not necessarily concurrent with the criteria used by voters [2].

Although there are objective criteria for assessing a politician whether he/she is a potential political representative, it is more 
intriguing to focus on subjective criteria to measure public perception.

While studying scholarly articles and research reports about assessment criteria for politicians, it has been noticed that there is no exiting literature on characterization of politician criteria based on generational differences. This paper would serve as a complement to intergeneration studies, as well

\section{MATERIALS AND METHODS}

The survey was conducted in Ulaanbaatar, Mongolia, randomly sampled 2721 respondents were subject to one-to-one interview by using a structured questionnaire to identify the basic criteria used by Mongolians to assess politician as a potential representative.

Respondents' profile is well distributed by sex, age, level of education and job types. This part complies with the voters' profile in the national parliamentary election in 2016 [3]. 46.6 percent of the respondents are female, the rest 53.3 percent are male. Also, 46.7 percent had undergraduate degree, 10.4 percent has graduate degree, 5.9 percent - vocational training and the remaining 37 percent were secondary or high school graduates.

In the following paper, we used open data of respondents' age and clustered them into four generations. Literature reveals that exactness in generation theories [4] hardly exists and varies among scholars and the range of age [5] [6] varies from one society to another ${ }^{1}$. In order to choose the appropriate range for each generation in Mongolia, we reviewed domestic scholarly works on intergenerational studies. As a result, it was revealed that there is almost as political opinion studies based in Mongolia.

A main contribution of this work is the quantitative demonstration of factors that can be used as a basic requirement for assessing politicians. A factor analysis has been conducted by the authors in order to identify the revolutionary nature of politics and its perception among public and the way it is characterized by different generations. no theoretical background that can be cited as a definition of what Mongolian generation implies.

Due to lack of literature, we decided to use the only existing source by Zorigt. D [7], a well-known social scientist, who defines Mongolian generations benchmarked with international classifications ${ }^{2}$. According to chosen age range, survey respondents comprised of Generation $\mathrm{Z}$ below 22 years of age to be 19 percent, Generation $Y$ between the age of 23 and 38 to be 43 percent, Generation $\mathrm{X}$ aged 39-54 - 26 percent, and Generation baby boomers (hereafter Generation BB) over 55 years of age at 12 percent.

Given the centrality of selecting the criteria for politician, we used 1 to 5 scale question with 20 criteria and used the subjective and rational evaluation of the respondents. Political and social surveys conducted by local research institutions and companies [8] [9] are used as the main sources to determine the 20 criteria used in this paper. Criteria are selected by the authors based on the results of desk review and factor analysis shows that these criteria are set appropriately.

1. Literature about the Generation Theory had started a century ago, based on Karl Mannheim 's work and has been developed by various scholars and social scientists. Practical importance of differentiating generations is appropriately addressed by research institutions, including the Pew Research Center and others in the field of politics, business and sociology.

2. D. Zorigt's work is analyzed on the basis of classification by the Pew Research Center and modified to Mongolian background on the basis of historically crucial social and political movements and events, and the Mongolian traditional approach to differentiate generations by 12 years. Authors clarified and consented about his study through a phone call. 


\section{RESULTS AND DISCUSSIONS}

Based on KMO measurement of the sampling adequacy and Bartlett's Test of Sphericity significance level equals, below factor analysis can be used as a set of criteria of a qualified politician among different generations in Mongolia. According to the result of factor analysis based on absolute significance value above 0.30 , it can be interpreted that 20 criteria are classified into 5 factors for each generation. Certain commonalities and discrepancies are observed among generations and analyzed accordingly.

One out of 20 items have shown significant level below 0.30 in factor analysis of each generation, which is 'having knowledge on international political issues'. Thus, it has been arranged to conduct correlation tests between items in terms of relevance as the below table and the result enabled to factorize the 3 items into one factor.

\section{Correlations}

\begin{tabular}{|c|c|c|c|c|c|}
\hline & & & $\begin{array}{l}\text { Having legal } \\
\text { and economic } \\
\text { knowledge } \\
\end{array}$ & $\begin{array}{c}\text { Having knowledge } \\
\text { on international } \\
\text { political issues }\end{array}$ & $\begin{array}{c}\text { Having } \\
\text { knowledge on key } \\
\text { domestic issues }\end{array}$ \\
\hline \multirow{9}{*}{ 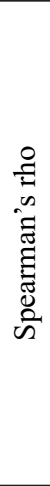 } & \multirow{3}{*}{$\begin{array}{l}\text { Having legal } \\
\text { and economic } \\
\text { knowledge }\end{array}$} & $\begin{array}{l}\text { Correlation } \\
\text { Coefficient }\end{array}$ & 1.000 & $0.042^{*}$ & $0.565^{* *}$ \\
\hline & & Sig. (2-tailed) & & 0.028 & 0.000 \\
\hline & & $\mathrm{N}$ & 2721 & 2721 & 2721 \\
\hline & \multirow{3}{*}{$\begin{array}{l}\text { Having } \\
\text { knowledge on } \\
\text { international } \\
\text { political issues }\end{array}$} & $\begin{array}{l}\text { Correlation } \\
\text { Coefficient }\end{array}$ & $0.042^{*}$ & 1.000 & $0.041^{*}$ \\
\hline & & Sig. (2-tailed) & 0.028 & & 0.033 \\
\hline & & $\mathrm{N}$ & 2721 & 2721 & 2721 \\
\hline & \multirow{3}{*}{$\begin{array}{l}\text { Having } \\
\text { knowledge on } \\
\text { key domestic } \\
\text { issues }\end{array}$} & $\begin{array}{l}\text { Correlation } \\
\text { Coefficient }\end{array}$ & $0.565^{* *}$ & $0.041^{*}$ & 1.000 \\
\hline & & Sig. (2-tailed) & 0.000 & 0.033 & \\
\hline & & $\mathrm{N}$ & 2721 & 2721 & 2721 \\
\hline
\end{tabular}

* Correlation is significant at the 0.05 level (2-tailed).

** Correlation is significant at the 0.01 level (2-tailed).

Politician criteria for Generation $\mathrm{Z}$ seems to be classified into 5 factors that are commonly identified as qualification, personal life, personal image, knowledge and public skills. As they understand education and experience as one factor, it therefore could be integrated into the qualification factor. Here, it seems that education is defined in a broader sense by Generation Z. In their view, education is not only the obtained degrees and schools completed, but also a part of life experience.

Generation Z clearly differentiates "Personal image", "Personal life" as separate factors and there are no significant overlapping items. However, statistics show considerable overlap between "knowledge" and "public skills" factors.
They perceive "being ethical" and "being innovative" is a type of knowledge that a politician would need to learn or train himself/ herself on how to behave ethically and in an innovative manner in order to prove his/ her political knowledge to the public. More interestingly, Generation $\mathrm{Z}$ perceives being ethical as a public skill. It could be interpreted that the younger generation in Mongolia emphasizes the importance of ethics in all areas of political knowledge and public representation.

Also, similar importance is given to foreign language skills that it is considered as knowledge and qualification at the same time, which possibly means that having foreign language skills is a standard norm for a politician. 
Table 1. Factor analysis of Generation Z

\begin{tabular}{|c|c|c|c|c|c|}
\hline \multicolumn{6}{|c|}{ Rotated Factor Matrix ${ }^{\mathrm{a}, \mathrm{b}}$} \\
\hline & \multicolumn{5}{|c|}{ Factor } \\
\hline & $\begin{array}{c}\text { 1. Qualifi- } \\
\text { cation }\end{array}$ & $\begin{array}{l}\text { 2. Personal } \\
\text { life }\end{array}$ & $\begin{array}{l}\text { 3. Personal } \\
\text { Image }\end{array}$ & $\begin{array}{l}\text { 4. Know- } \\
\text { ledge }\end{array}$ & $\begin{array}{l}\text { 5. Public } \\
\text { Skills }\end{array}$ \\
\hline High education level & 0.610 & & & & \\
\hline $\begin{array}{l}\text { Being a graduate of a prestigious foreign } \\
\text { university }\end{array}$ & 0.621 & & & & \\
\hline Having foreign language skills & 0.509 & & & 0.420 & \\
\hline Having political experience & 0.581 & & & & \\
\hline $\begin{array}{l}\text { Working experience in government } \\
\text { service }\end{array}$ & 0.567 & & & & \\
\hline Having organized public activities & 0.504 & & & & \\
\hline Having a stable family life & & 0.628 & & & \\
\hline $\begin{array}{l}\text { Being meritocratic and having ordinary } \\
\text { family background }\end{array}$ & & 0.637 & & & \\
\hline Having less rumor and sensation & & 0.617 & & & \\
\hline Appearance & & & 0.621 & & \\
\hline Having a sense of aesthetics & & & 0.785 & & \\
\hline Physical development & & & 0.761 & & \\
\hline Appropriateness of dressing and image & & & 0.711 & & \\
\hline Having legal and economic knowledge & 0.321 & & & 0.660 & \\
\hline \multicolumn{6}{|l|}{$\begin{array}{l}\text { Having knowledge on international } \\
\text { political issues }\end{array}$} \\
\hline $\begin{array}{l}\text { Having knowledge on key domestic } \\
\text { issues }\end{array}$ & & & & 0.777 & \\
\hline Behaving ethically & & & & 0.695 & 0.333 \\
\hline Having a sense of humor & & & & & 0.520 \\
\hline Being innovative & & & & 0.557 & 0.559 \\
\hline Being charismatic & & & & & 0.703 \\
\hline
\end{tabular}

KMO measurement of the sampling adequacy $=0.906$

Bartlett's Test of Sphericity significance level $=0.000$

Extraction Method: Principal Axis Factoring

Rotation Method: Varimax with Kaiser Normalization

a. Rotation converged in 6 iterations

b. Only cases for which generation $=Z$ are used in the analysis phase

Factor analysis reveals that there is only a slight difference between perception of politician criteria among Generation $\mathrm{Z}$ and Generation Y. Experience in government service and organization of public activities are subscribed into the personal life factor rather than political qualification. There might be a general assumption among Generation $\mathrm{Y}$ according to whom experience in working in government service and involvement in public activities are not meritocratic or prestigious enough to qualify a person to assess them as their political representation.

Being a graduate of a prestigious foreign university is a type of personal image according to Generation Y. While Generation $\mathrm{Z}$ perceives that being a graduate of a prestigious foreign university is a qualification, while Generation $\mathrm{Y}$ believes that this would not reveal the level of qualification of a politician, rather considered as an image. 
Table 2. Factor analysis of Generation $Y$

\begin{tabular}{|c|c|c|c|c|c|}
\hline \multicolumn{6}{|c|}{ Rotated Factor Matrix ${ }^{a, b}$} \\
\hline & \multicolumn{5}{|c|}{ Factor } \\
\hline & $\begin{array}{c}\text { 1. Qualifi- } \\
\text { cation }\end{array}$ & $\begin{array}{l}\text { 2. Personal } \\
\text { life }\end{array}$ & $\begin{array}{l}\text { 3. Personal } \\
\text { Image }\end{array}$ & $\begin{array}{l}\text { 4. Know- } \\
\text { ledge }\end{array}$ & $\begin{array}{l}\text { 5. Public } \\
\text { Skills }\end{array}$ \\
\hline High education level & 0.624 & & & & \\
\hline $\begin{array}{l}\text { Being a graduate of a prestigious foreign } \\
\text { university }\end{array}$ & 0.535 & & 0.317 & & \\
\hline Having foreign language skills & 0.634 & & & & \\
\hline Having political experience & 0.554 & & & & \\
\hline $\begin{array}{l}\text { Working experience in government } \\
\text { service }\end{array}$ & 0.393 & 0.398 & & & \\
\hline Having organized public activities & 0.368 & 0.486 & & 0.355 & \\
\hline Having a stable family life & & 0.519 & & & \\
\hline $\begin{array}{l}\text { Being meritocratic and having ordinary } \\
\text { family background }\end{array}$ & & 0.750 & & & \\
\hline Having less rumor and sensation & & 0.642 & & & \\
\hline Appearance & & & 0.714 & & \\
\hline Having a sense of aesthetics & & & 0.845 & & \\
\hline Physical development & & & 0.802 & & \\
\hline Appropriateness of dressing and image & & & 0.629 & & \\
\hline Having legal and economic knowledge & & & & 0.647 & \\
\hline \multicolumn{6}{|l|}{$\begin{array}{l}\text { Having knowledge on international } \\
\text { political issues }\end{array}$} \\
\hline $\begin{array}{l}\text { Having knowledge on key domestic } \\
\text { issues }\end{array}$ & & & & 0.781 & \\
\hline Behaving ethically & & & & 0.485 & \\
\hline Having a sense of humor & & & 0.339 & & 0.325 \\
\hline Being innovative & & & & 0.364 & 0.555 \\
\hline Being charismatic & & & & & 0.471 \\
\hline
\end{tabular}

KMO measurement of the sampling adequacy $=0.875$

Bartlett's Test of Sphericity significance level $=0.000$

Extraction Method: Principal Axis Factoring

Rotation Method: Varimax with Kaiser Normalization

a. Rotation converged in 6 iterations

$b$. Only cases for which generation $=Y$ are used in the analysis phase

According to statistics, Generations $\mathrm{X}$ and $\mathrm{BB}$ differentiate education and experience as separate factors, whereas younger generations perceive them in similar category. It seems that older generations in Mongolia emphasize higher education degree and graduation from prestigious universities as one independent factor to evaluate a politician. There might exist a stereotype among Generation $\mathrm{X}$, which simply states better the politician is educated, that better he/she would be a political representative.

Likewise, according to Generation Z, having foreign language skills corresponds to education and knowledge factors, which is a similar view held by Generation X. This coincidence can be elaborated in accordance with education reforms in Mongolia. For instance: English language was included in the curriculum of high school education for 
Generation Z, whereas Russian language was a compulsory course [10] for all high school students at a time when Generation X were in high school. Therefore, these generations recognize having foreign language skills as a standard knowledge norm for a politician. However, Generation Y, as a witness of the transitional period of education reforms in Mongolia, maintain that having foreign language skills is not a standard norm but a requisite qualification.
Another interesting statistics revealed by Table 3 is that being ethical, being charismatic and being innovative are included in the knowledge factor. Compared with younger generations, Generation $\mathrm{X}$ gives more emphasis on being charismatic to be characterized as a part of knowledge factor, which means that a politician should know how to act charismatic. In other words, Generation $\mathrm{X}$ assesses charisma as conceptually closer to knowledge than political experience.

Table 3. Factor analyses of Generation X

\begin{tabular}{|c|c|c|c|c|c|}
\hline \multicolumn{6}{|c|}{ Rotated Factor Matrix ${ }^{\mathrm{a}, \mathrm{b}}$} \\
\hline & \multicolumn{5}{|c|}{ Factor } \\
\hline & $\begin{array}{l}\text { 1. Edu- } \\
\text { cation }\end{array}$ & $\begin{array}{l}\text { 2. Political } \\
\text { experience }\end{array}$ & $\begin{array}{l}\text { 3. Per- } \\
\text { sonal life }\end{array}$ & $\begin{array}{l}\text { 4. Personal } \\
\text { Image }\end{array}$ & $\begin{array}{l}\text { 5. Know- } \\
\text { ledge }\end{array}$ \\
\hline High education level & 0.686 & & & & \\
\hline $\begin{array}{l}\text { Being graduate of a prestigious foreign } \\
\text { university }\end{array}$ & 0.530 & & & & \\
\hline Having foreign language skills & 0.563 & & & & 0.307 \\
\hline Having political experience & 0.424 & 0.395 & & & \\
\hline Working experience in government service & & 0.779 & & & \\
\hline Having organized public activities & & 0.547 & & & \\
\hline Having a stable family life & & & 0.486 & & \\
\hline $\begin{array}{l}\text { Being meritocratic and having ordinary fam- } \\
\text { ily background }\end{array}$ & & & 0.797 & & \\
\hline Having less rumor and sensation & & & 0.555 & 0.350 & \\
\hline Appearance & & & & 0.752 & \\
\hline Having a sense of aesthetics & & & & 0.800 & \\
\hline Physical development & & & & 0.845 & \\
\hline Appropriateness of dressing and image & & & & 0.681 & \\
\hline Having legal and economic knowledge & & & & & 0.521 \\
\hline \multicolumn{6}{|l|}{$\begin{array}{l}\text { Having knowledge on international political } \\
\text { issues }\end{array}$} \\
\hline Having knowledge on key domestic issues & & & & & 0.629 \\
\hline Behaving ethically & & & & & 0.629 \\
\hline \multicolumn{6}{|l|}{ Having a sense of humor } \\
\hline Being innovative & & & & & 0.568 \\
\hline Being charismatic & & & 0.304 & & 0.442 \\
\hline
\end{tabular}

KMO measurement of the sampling adequacy $=0.867$

Bartlett's Test of Sphericity significance level $=0.000$

Extraction Method: Principal Axis Factoring

Rotation Method: Varimax with Kaiser Normalization

a. Rotation converged in 7 iterations

b. Only cases for which generation $=X$ are used in the analysis phase 
Based on tables 3 and 4, it can be interpreted that Generation BB and Generation X have common criteria for politicians, especially in terms of education and political experience. The only distinction observed in knowledge factor is charisma, which the Generation BB is likely to associate with political experience and personal image. Sense of humor is understood as an ingredient of personal image, but also of political experience in the perception of Generation BB.
On the other hand, "Political experience" and "Knowledge" factors are more complex and could be elaborated in depth. Overlapping items, which are identified under public skills factor according to Generation $\mathrm{Z}$ and $\mathrm{Y}$, are partially political experience and knowledge according to Generation BB. This reveals the fact that politics was not conceived as public activity in their mindset, maybe leading to prevalent political culture in Mongolia before 1990.

Table 4. Factor analyses of Generation $B B$

\begin{tabular}{|c|c|c|c|c|c|}
\hline \multicolumn{6}{|c|}{ Rotated Factor Matrix $^{a}$} \\
\hline & \multicolumn{5}{|c|}{ Factor } \\
\hline & $\begin{array}{l}\text { 1. Edu- } \\
\text { cation }\end{array}$ & $\begin{array}{l}\text { 2. Political } \\
\text { experience }\end{array}$ & $\begin{array}{l}\text { 3. Personal } \\
\text { life }\end{array}$ & $\begin{array}{l}\text { 4. Personal } \\
\text { Image }\end{array}$ & $\begin{array}{l}\text { 5. Know- } \\
\text { ledge }\end{array}$ \\
\hline High education level & 0.584 & & & & \\
\hline $\begin{array}{l}\text { Being graduate of a prestigious foreign } \\
\text { university }\end{array}$ & 0.518 & 0.370 & & & \\
\hline Having foreign language skills & 0.863 & & & & \\
\hline Having political experience & 0.361 & 0.510 & & & \\
\hline Working experience in government service & & 0.767 & 0.332 & & \\
\hline Having organized public activities & & 0.600 & 0.352 & & \\
\hline Having a stable family life & & & 0.634 & & \\
\hline $\begin{array}{l}\text { Being meritocratic and having ordinary } \\
\text { family background }\end{array}$ & & & 0.832 & & \\
\hline Having less rumor and sensation & & & 0.708 & 0.309 & \\
\hline Appearance & & & & 0.752 & \\
\hline Having a sense of aesthetics & & & & 0.852 & \\
\hline Physical development & & & & 0.807 & \\
\hline Appropriateness of dressing and image & & & & 0.617 & \\
\hline Having legal and economic knowledge & & & & & 0.604 \\
\hline \multicolumn{6}{|l|}{$\begin{array}{l}\text { Having knowledge on international politi- } \\
\text { cal issues }\end{array}$} \\
\hline Having knowledge on key domestic issues & & & & & 0.741 \\
\hline Behaving ethically & & & & & 0.618 \\
\hline Having a sense of humor & & 0.376 & & 0.399 & \\
\hline Being innovative & & 0.310 & & & 0.434 \\
\hline Being charismatic & & 0.417 & & 0.302 & 0.397 \\
\hline
\end{tabular}

KMO measurement of the sampling adequacy $=0.833$

Bartlett's Test of Sphericity significance level $=0.000$

Extraction Method: Principal Axis Factoring

Rotation Method: Varimax with Kaiser Normalization

a. Rotation converged in 6 iterations

b. Only cases for which generation $=\mathrm{BB}$ are used in the analysis phase 
Research findings potentially indicate key differences in perception of criteria for politicians among different generations in Mongolia. Even though the authors admit that there is a room for improvement, especially the 20 items analyzed in factor analysis are chosen from non-exhaustive and subjective list of politician criteria, therefore, it should be verified by further research and other quantitative analysis. At least intercorrelational analysis would be an option for research improvement. Conducting content analysis on existing political reports and other materials or some qualitative survey would also be a good complement for this paper.

Given the nature of the questionnaire, respondents were highly rationale when answering the questions. This can be adjusted by other methodologies and the results can be compared in the future studies. Moreover, the generation classification used in this research has not yet been confirmed to be the ideal theory among Mongolian social scientists. Thus, any critics about the research methodology is welcomed by the authors for further adjustments.

\section{CONCLUSIONS}

Intergeneration studies are rare in Mongolian science practice and the authors take this chance to contribute a complementary knowledge about characterization of politician criteria among generations. Although this research is not a new discovery, a practical importance underlies for future factor analysis on other variables that reflect intergeneration effects.

A rough estimation of above factor analysis indicates that Generations BB and X; Generations $\mathrm{Y}$ and $\mathrm{Z}$ are closer to each other in terms of identified politician criteria. Personal image and personal life factors are almost identically perceived by the four generations. Given the magnitude of knowledge factor, each knowledge items are factorized together with ethics in every generations, which indicates that ethics is also an essential knowledge, which is especially a must for politicians in Mongolia.

Despite such commonality, significant discrepancies are observed in education factor, which younger generations characterize education as a part of political qualification and combine education and political experience in a single factor. Also, they identify public skills of politician as one significant factor. On the other hand, older generations tend to factorize political experience and education as separate factors.

\section{REFERENCES}

1. R. Murray, "What makes a good politician? Reassessing the criteria used for political recruitment," Politics and Gender, vol. 11, no. 4, pp. 770-776, 2015.

2. R. Campbell \& P. Cowley, "What voters want: Reactions to candidate characteristics in a survey experiment," Vol. 62, no. 3, pp. 745-765, 2014.

3. National Statistics Office, 2019. [Online]. Available: http://1212.mn/Stat.aspx?LIST_ ID=976_L02\&type=tables . [Accessed 1908 2019].

4. K. Mannheim, "The problem of generations," Psychoanalytic review, vol. 57, no. 3, pp. 378-404, 1970.

5. "The whys and hows of generations," Pew Research Center, 2015.

6. "Most Millennials resist the Millennial label," Pew Research Center, 2015.

7. D. Zorigt, "About the Generations in Mongolia," in Annual Conference by Department of 
Philisophy, National University of Mongolia, Ulaanbaatar, 2015.

8. "The Political Participation Survey of Mongolia Youth between 18 to 35," Academy of Management Mongolia, Ulaanbaatar, 2016.

9. "The Survey of National Media Usage by Generations," Ulaanbaatar, 2019.

10. N. A. Svedlova \& U. Enkhbaatar , "The Russian Language: History and Perspectives of Studying in Mongolia," Journal of Eastern Siberia on Science and Education, p. 4, 2015. 